\title{
Dynamics of peripheral blood flow for endophyte-naïve cattle fed toxic tall fescue seed
}

\author{
G.E. AIKEN, B.H. KIRCH and J.R. STRICKLAND \\ USDA-ARS, Forage-Animal Production Research Unit \\ University of Kentucky \\ N-220 Ag. Science North \\ Lexington, $K Y 40546$ \\ geaiken@ars.usda.gov
}

\begin{abstract}
Doppler ultrasonography was used to measure blood flow dynamics in the caudal artery of heifers that were fed diets with either endophyte-infected $(\mathrm{E}+)$ or non-infected $(\mathrm{E}+)$ tall fescue (Festuca arundinacea Schreb.) seed. Heifers were assigned to six pens and during an adjustment period were fed alfalfa hay for $5 \mathrm{~d}$, and then the hay plus a concentrate with E- tall fescue seed for 9 d. An 11-d experimental period followed with three pens being changed to hay plus concentrate with E+ seed. Caudal artery area in E+ heifers had declined by $4 \mathrm{~h}$ from the initial feeding of the E+ diet before stabilising at the lower level between 4 and $28 \mathrm{~h}$. Heart rates followed a similar trend. Blood flow rate was lower in E+ heifers from $28 \mathrm{~h}$ onwards. Results indicated that vasoconstriction can occur in cattle within $28 \mathrm{~h}$ from initial consumption of toxic fescue.
\end{abstract}

Keywords: tall fescue, fescue toxicosis, cattle, vasoconstriction

\section{Introduction}

Cattle that consume ergot alkaloids produced by an endophytic fungus (Neotyphodium coenophialum) that inhabits tall fescue can be inflicted with "fescue toxicosis". The malady has symptoms that include retention of rough hair coat, elevated body temperature, laboured respiration, and decreased serum prolactin (Schmidt \& Osborn 1993). Cattle exhibiting symptoms of fescue toxicosis may undergo severe heat stress at the onset of high ambient temperature and relative humidity (Hemken et al. 1981; Spiers et al. 2004).

Doppler ultrasonography has been used to study blood flow characteristics in horses (Hoffman et al. 2001; Mario et al. 1997; Rasis et al. 2000). Although use of the technology with cattle has been limited, it has shown to have the repeatability (King 2006) to provide objective measures of vasoconstriction and blood flow in cattle exhibiting fescue toxicosis. An experiment was conducted to compare hemodynamics in heifers fed diets with either E+ or E- tall fescue seed.

\section{Materials and Methods}

Eighteen crossbred heifers (Angus x Brangus) 12 to 14 months of age were used. Diets of the heifers did not contain ergot alkaloids from birth until the beginning of the experiment. The heifers were stratified by body weight $[375 \pm 17 \mathrm{~kg}$ (s.d.)] for assignment to six pens (three heifers/pen). Treatment diets, containing either E- or E+ tall fescue seed, were assigned to pens in a completely randomised design with three replications. During an adjustment period, chopped alfalfa hay was fed to each pen for 5 days followed by feeding the chopped hay $(54.4 \%$ of DM) mixed with concentrate with E- seed (45.6\% of DM) for 9 days. An 11-d experimental period followed with the feeding of both treatment diets. Composition of the concentrate was ground soybean hulls $(47.6 \%$ of DM), tall fescue seed $(47.6 \%$ of DM), mineral premix $(1.2 \%$ of DM), and molasses $(3.6 \%$ of DM).
The alfalfa-concentrate mixtures were fed ad libitum during the adjustment and experimental periods at $0900 \mathrm{~h}$ each morning. Refusals were collected daily prior to feeding, dried in a forcedair oven, and weighed to estimate daily DM consumption. Daily ambient temperatures were obtained from a weather station at the research center.

Each concentrate mixture was subsampled on the first and last days of the experimental period. Samples were stored frozen, freeze dried, ground through a 1-mm screen, and assayed for ergovaline using HPLC fluorescence with a modified procedure developed by Yates and Powell (1988).

Blood was collected from the jugular vein of each heifer at $144,-96,28,52,76,96,172$, and $268 \mathrm{~h}$ relative to initial feeding E + tall fescue seed. Blood was centrifuged to obtain serum, and stored at $0^{\circ} \mathrm{C}$. Serum was assayed for prolactin following procedures of Bernard et al. (1993).

Baseline ultrasound measures were taken during the adjustment period at $-144,-96$, and $-72 \mathrm{~h}$ relative to the initial feeding of $\mathrm{E}+$ seed, and measurements were taken during the experimental period at 4, 28, 52, 76, 96, 172, $268 \mathrm{~h}$ relative to initial feeding of E+ seed (Fig. 1). Ultrasound scans of the caudal artery at the fourth coccygeal $(\mathrm{Cd} 4)$ vertebrae were taken using an Aloka Prosound Ultrasound Unit ${ }^{\mathrm{b}}$ with a UST-5542 (13 MHz) linear array transducer set to a depth of $2 \mathrm{~cm}$. Three cross-sectional Doppler flow scans were taken to determine mean artery lumen area. This flow signal was used to estimate lumen area. Three Doppler spectra with a longitudinal transducer orientation also were collected. Spectra were taken with a Doppler frequency of $6 \mathrm{MH}$ and a correction angle of $25^{\circ}$. Sample volume was set at $0.5 \mathrm{~mm}$. Doppler gain was set at 40 , the maximum setting before noise became apparent. Peak systolic velocity, end diastolic velocity, mean velocity, and flow rate per minute were measured over three cardiac cycles within each scan and then averaged over the three scans.

Repeated measures analysis was performed for each response variable using mixed models (Littell et al. 1996). The statistical model evaluated effects of treatment diet, measurement day relative to initial feeding of $\mathrm{E}+$ seed, and interaction between the two variables. Orthogonal contrasts were used if the interaction was significant $(\mathrm{P}<0.10)$ to determine differences between diets within each measurement day.

\section{Results and Discussion}

Ambient temperatures during most of the experiment were less than $10^{\circ} \mathrm{C}$ and fell slightly below $0^{\circ} \mathrm{C}$ on the first and second days of the experimental period. Ambient temperature tended to increase over the remainder of the experimental period up until the last day when the highest ambient temperature during the experiment was recorded. Controlled experiments with cattle consuming $\mathrm{E}+$ fescue seed have reported increases in core body temperature as compared to cattle on nontoxic diets as ambient temperature changed from thermoneutral to those at or above 
$31^{\circ} \mathrm{C}$ (Aldrich et al. 1993; Al-Haidary et al. 2001). However, the objective of the present experiment was to measure response of the bovine vascular system to the ergot alkaloids without combining the effect of heat on the physiology of the heifers.

Daily dry matter consumption averaged $6.3 \pm 0.5$ (SEM) kg per heifer during the adjustment period when the E- diet was fed to all pens. During the experimental period, dry matter consumption of heifers fed the concentrate with E- seed was $10.7 \pm 0.5 \mathrm{~kg}$ dry matter/heifer, and for heifers fed the concentrate with E+ seed it was $9.0 \pm 0.8 \mathrm{~kg}$ dry matter/heifer. Chopped alfalfa hay plus concentrate containing E+ seed had $0.85 \mu \mathrm{g}$ ergovaline/g DM.

There was a treatment diet by measurement hour interaction $(\mathrm{P}<0.001)$ on serum prolactin concentration (Fig. 2). Prolactin concentrations were consistently lower $(\mathrm{P}<0.05)$ during the experimental period for the $\mathrm{E}+$ diet, starting at $28 \mathrm{~h}$ from the initial feeding of the E+ diet. During the experimental period, serum prolactin with the $\mathrm{E}+$ diet averaged $20 \mathrm{ng} / \mathrm{mL}$ and for the E- diet it averaged $109 \mathrm{ng} / \mathrm{mL}$. Baseline measures were high $(252 \mathrm{ng} / \mathrm{mL})$ and declined for both diets by $28 \mathrm{~h}$ from the initial feeding of E+ seed, which coincided with rapid declines in ambient temperatures. Ergot alkaloids stimulate dopamine-2 receptor sites and cause a decrease in serum prolactin (Oliver 2004). Reduced serum prolactin concentrations with the $\mathrm{E}+$ diet indicated that consumption of alkaloids was above the threshold to elicit a response.

A treatment diet by measurement hour interaction $(\mathrm{P}<0.001)$ on caudal artery area indicated that artery areas declined during

Figure 1 Diets during adjustment and experimental periods, and hours relative to initial feeding of $E+$ seed when ultrasound data were collected.

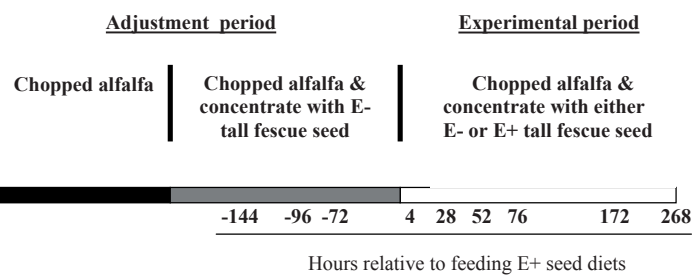

Figure 2 Trends in serum prolactin concentrations over the adjustment (baseline) and experimental periods for heifers fed diets with either endophyte-infected $(E+)$ of non-infected (E-) tall fescue seed during the experimental period. Diet interacted with hours from initial feeding of $\mathrm{E}+$ seed in affecting serum prolactin concentrations $(P<0.001)$. Negative hours represent baseline measures taken during the adjustment period.

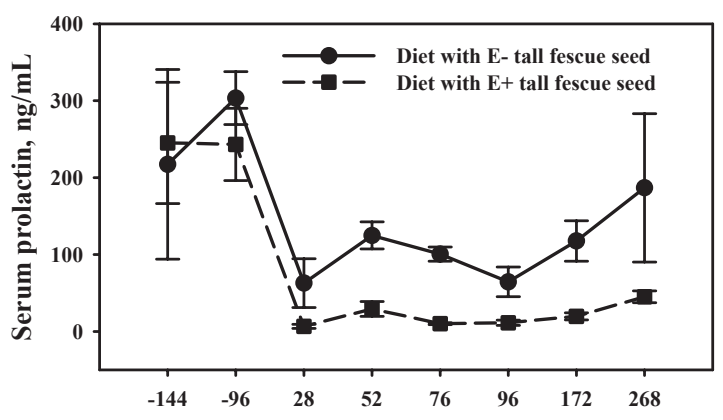

Hours from initial feeding of $\mathrm{E}+$ tall fescue seed the experimental period for the $\mathrm{E}+\operatorname{diet}$ (Fig. 3A). Baseline areas for the $\mathrm{E}+$ diet averaged $4.7 \mathrm{~mm}^{2}$ and areas had declined $(\mathrm{P}<0.10)$ compared to those measured for the $\mathrm{E}$ - diet by $4 \mathrm{~h}$ from the initial feeding the $\mathrm{E}+$ diet. Further declines in artery areas were observed for the $\mathrm{E}+$ diet at $28 \mathrm{~h}$ and were consistently lower $(\mathrm{P}<0.001)$ for the remainder of the experimental period. Artery areas for the E- diet group averaged $5.3 \mathrm{~mm}^{2}$ across measurement hours, but varied considerably within and between pens.

There was a treatment diet by measurement hour interaction $(\mathrm{P}<0.05)$ on heart rate (Fig. 3B). Baseline heart rates for the treatment diets averaged 105 beats $/ \mathrm{min}$, but heart rate was lower $(\mathrm{P}<0.05)$ for the $\mathrm{E}+$ diet group at $28 \mathrm{~h}$ from initial feeding of $\mathrm{E}+$ diet. Heart rate with the $\mathrm{E}+$ diet was lower than those with the E- diet for the remainder of the experimental period. Relative to heifers on the E- diet, heifers on the E+ diet had a $20 \%$ decline in heart rate during the 28 to $268 \mathrm{~h}$ period from initial feeding of the $\mathrm{E}+$ diet. However, heart rates for these heifers tended to increase towards the end of the period to the baseline measure. It cannot be determined from the data if ergot alkaloids had a direct effect on heart rate, but it likely was a reflex to increases in blood pressure from vasoconstriction (Berne \& Levy 1992).

A treatment diet by measurement hour interaction on caudal blood flow rate per min resulted from a decline in blood flow with the $\mathrm{E}+\operatorname{diet}$ (Fig. 3C). Baseline flow rates for both treatment

Figure 3 Changes in Doppler ultrasound measures of causal artery area $(A)$, heart rate $(B)$, and blood flow rate $(C)$ through the caudal artery for heifers fed either endophyteinfected $(E+)$ or non-infected ( $E-)$ tall fescue seed. Negative hours represent baseline measures taken during the adjustment period when all heifers were fed with E- seed.
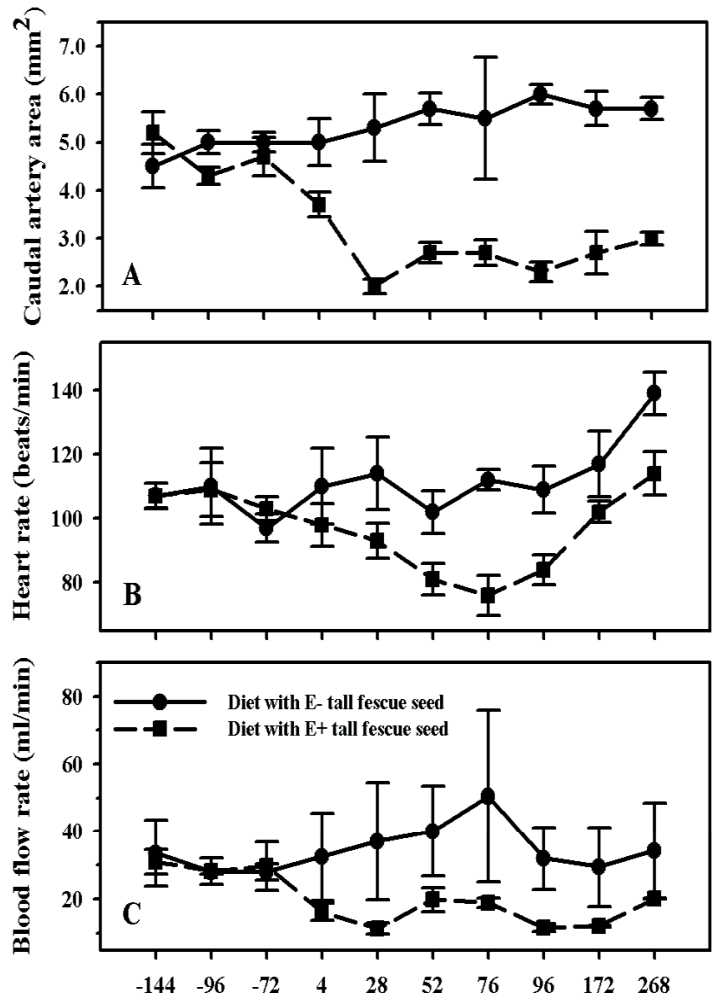

Hours from initial feeding $\mathrm{E}+$ tall fescue seed 
diets averaged $29.7 \mathrm{~mL} / \mathrm{min}$, and averaged 36.5 and $15.7 \mathrm{~mL} / \mathrm{s}$ for $\mathrm{E}-$ and $\mathrm{E}+$ diets, respectively, during the experimental period. Therefore, there was a $57 \%$ decrease in flow rate for the E+ heifers relative to those on the E- diet. Significant differences $(\mathrm{P}<0.05)$ were determined at 28 and $76 \mathrm{~h}$ and tendencies $(\mathrm{P}<0.2)$ were observed at 52 and $96 \mathrm{~h}$.

Caudal artery area, heart rate, and blood flow rate were more variable with the E- than the $\mathrm{E}+$ diet. Vasoconstriction caused by the ergot alkaloids likely reduced the influence that environmental stimuli, such as ambient temperature, have on constriction or dilation within the vascular system. Ultrasonic measures varied within and between heifers on the E- diet, which was likely related to the variation in ambient temperature that was observed in the experiment.

\section{Conclusion}

This experiment shows that vasoconstriction combined with reductions in heart rate occur in cattle within 24 hours following consumption of $\mathrm{E}+$ tall fescue. Further research is needed to determine sensitivity of the bovine vascular system over a range of ergovaline concentrations.

\section{REFERENCES}

Aldrich, C.G.; Paterson, J.A.; Tate, J.L. 1993. The effects of endophyte-infected consumption on diet utilization and thermal regulation in cattle. Journal of Animal Science 71: 164-179.

Al-Haidary, A.; Spiers, D.E.; Rottinghaus, G.E. 2001. Thermoregulatory ability of beef heifers following intake of endophyte-infected tall fescue during controlled heat challenge. Journal of Animal Science 79: 1780-1788.

Bernard, J.K.; Chestnut, A.B.; Erickson, B.H. 1993. Effects of prepartum consumption of endophyte-infected tall fescue on serum prolactin and subsequent milk production. Journal of Dairy Science 76: 1928-1933.

Berne, R.M., Levy, MN. 1992. Regulation of the heartbeat. In:
Cardiovascular Physiology. $6^{\text {th }}$ ed. Mosby-Year Book, Inc.

Hemken, R.W.; Boling, J.A.; Bull L.S. 1981. Interaction of environmental temperature and anti-quality factors on the severity of summer fescue toxicosis. Journal of Animal Science 52: 710-714.

Hoffman, K.L.; Wood, A.K.W.; Griffiths, K.A. 2001. Doppler sonographic measurements of arterial blood flow and their repeatability in the equine foot during weight and non-bearing. Research in Veterinary Science 70:199-203.

King, A.M. 2006. Development, advances, and applications of diagnostic ultrasound in animals. Veterinary Journal 171: 408-420.

Littell, R.C.; Milliken, G.A.; Stroup, W.W. 1996. SAS System for Mixed Models. SAS Inst. Inc., Cary, NC.

Mario, C.; Pietra, M.; Gandini G. 1997. Pulsed wave-doppler ultrasonography evaluation of the common carotid artery in the resting horse: Physiologic data. Veterinary Radiology \& Ultrasonography 38:200-206.

Oliver, J.W. Pathophysiologic response to endophyte toxins. pp. 291-304 In: Neotyphodium in Cool-Season Grasses. Eds. Roberts, C.A.; West, C.P.; Spiers, D.E., Blackwell Publishing, Ames, IA.

Raisis, A.L.; Young, L.E.; Meire, H.B. 2000. Variability of dopper ultrasound measurements of hindlimb blood flow in conscious horses. Equine Veterinary Journal 32: 125-132.

Schmidt, S.P.; Osborn, T.G. 1993. Effects of endophyte-infected tall fescue on animal performance. Agricultural Ecosystems and Environments 44: 233-262.

Spiers, D.E.; Evans, T.J.; Rottinghaus, G.E. 2004. Interaction between thermal stress and fescue toxicosis: Animal models and new perspectives. pp. 243-270 In: Neotyphodium in coolseason grasses. Eds. Roberts, C.A.; West, C.P.; Spiers, D.E., Blackwell Publishing, Ames, IA.

Yates, S.G.; Powell, R.G. 1988. Analysis of ergopeptine alkaloids in endophyte-infected tall fescue. Journal of Agricultural Food Chemistry 36: 337-340. 